\title{
GONDOLATOK VÁLLALATI INFORMÁCIÓS RENDSZEREKRŐL
}

\author{
Hampel György
}

\section{SUMMARY}

Large and medium-sized enterprises cannot get along without an information system; these firms have become heavily computer-dependent. This paper briefly summarizes the possible needs and their reasons; it describes how the continuously developing information systems can be categorized based on their services; it covers the options enterprises have to implement such systems (to develop, to buy a standard system or to outsource). The paper also deals with the fact that when investing in an information system, return on investment is an important factor but the consequences of the lack of investment has to be considered as well. The final section covers some aspects of the enterprise systems and their influence on the enterprise competitiveness.

\section{BEVEZETÉS}

Ma, a 21. század elején elmondhatjuk, hogy különböző méretü, képességü és teljesítményủ számítógépekkel az élet szinte valamennyi területén találkozhatunk. Így van ez a vállalkozások esetében is, ahol a nagy és közepes méretü vállalkozások esetében is gyakorlatilag a vállalkozások számítógépes függőségéről beszélhetünk, legyen szó akár a napi rutinfeladatok végrehajtásáról, a számítógépesített gyártásról, vagy akár a döntéshozatalról (Tarnóczi 2008).

Bár informatikai támogatást nem igénylő tevékenységek végzésekor egy kisvállalkozás ma még elboldogulhat hagyományos, számítógépes támogatást nélkülöző információs eszközökkel is, egy nagyobb vállalkozás aligha engedheti meg magának, hogy ne használjon korszerú, számítógéppel támogatott információs rendszert, hiszen egyre nagyobb tömegü adatot kell gyüjtenie, tárolnia és továbbítania, ugyanakkor mindehhez egyre kevesebb idő áll rendelkezésére, továbbá egyre bonyolultabb feldolgozásokra van igény - remélhetőleg - a vezetés részéröl. Egy elvileg tökéletesen felépített információs rendszer sem képes az előbb felsorolt feladatokat számítógépes támogatás nélkül megoldani (Gábor 1993). Ha pedig nem gondoskodunk a felhalmozott adatvagyon számítógépesített információs rendszerekkel történő kiaknázásáról, az adathalmazaink ritkán látogatott, adatarchívumokká, ,,adatsírokká” válhatnak (Han-Kamber 2004).

A vállalati informatika az ismeretfeldolgozás új technikájával és alkalmazási sajátosságaival kialakult új termelőerő, új erőforrás (Arató-Schwarczenberger 1993), amely a vállalatokban folyó irányítási és termelömunka területén hoz változásokat (Bodnár 2008). Középpontjában a megfelelő minőségü, idejü és pontosságú, releváns információk megszerzése, tárolása és biztosítása áll, megfelelő költségekkel és az információhoz való megfelelő hozzáférés biztosításával (Ward 1998). A vállalkozás környezeti adatainak figyelésével és elérésével egyidejűleg kezeli a szervezeten belül zajló tevékenységek és a környezettel folytatott tranzakciók adatait is (Murdick 1980) (Lucey 1989). Lényegében a vállalkozás információszükségletének legtöbb feladatát kielégítő számítógépes programgyüjteményről van szó (Wallace-Kremzar 2006), amely 
ellátja a közép- és felsővezetést azokkal az információkkal, amelyek ahhoz szükségesek, hogy ellenőrizni és irányítani tudják azokat a tevékenységeket, amelyekért felelösek (Smyth 1977).

\section{IGÉNYEK, ELVÁRÁSOK}

Az elmúlt másfél évtized dinamikus növekedése után elmondható, hogy a nagy- és közepes vállalkozások esetében gyakorlatilag telített a piac, ami az üzleti szoftverek iránti igényt illeti (Cégvezetés 2007a), és ma már a fejlesztők számára üzleti lehetőséget jelentenek a kisvállalkozások is. Tulajdonképpen cégmérettől függetlenül mindenki számára található olyan informatikai megoldás, amely képes az elvárások kielégítésére (Barna 2006), még Magyarországon is.

Mi motiválhatja a vállalkozások vezetését, tulajdonosait a számítógéppel támogatott információs rendszer kiépítésére és használatára?

A motiváció adódhat külső kényszerből, hiszen a vállalkozás tevékenységével összefüggő feladatokhoz kapcsolódhatnak hazai és nemzetközi (biztonsági) elöírások (McMeekin et al. 2006), amelyek igénylik a nyersanyag, a termék, ill. az áruforgalom pontos nyomon követését (Élelmiszer 2007).

Származhat belső kényszerből, hiszen a vezetés gondolhatja úgy, hogy a vállalkozás versenyképessége múlhat az információ (és a hozzá kapcsolódó információs rendszer) kiemelt erőforrásként történő kezelésétől. Ilyenkor a termelékenységhez, a vállalkozás hatékony müködéséhez kapcsolódó tényezők következtében használnak olyan rendszereket, amelyekkel lehetővé válik a termelési folyamatok hatékony irányítása (Akkerman-Donk 2008), a logisztikai folyamatok támogatása (Mangina-Vlachos 2005). A könyvelési és egyéb pénzügyi háttér lefedése, illetve a beszerzési és értékesítési folyamatok áttekinthetőségének biztosítása (Élelmiszer 2006) és nem utolsó sorban a vezetés különböző szintjein a döntéshozatal támogatása.

A vállalkozás vezetésének tehát fel kell ismernie, hogy a hatékony müködés érdekében szükség van olyan informatikai rendszer müködtetésére, amely átszövi az egész vállalkozást, ellátja az adminisztratív és a termeléssel összefüggő feladatok támogatását, továbbá eszközöket biztosít a vezetés különbözö szintjei számára a döntések meghozatalában.

Ma már azonban nem elegendő az üzleti igények teljes kiszolgálása. Az korszerü információs rendszernek hozzá kell járulnia a vállalkozás növekedéséhez is. Az általános üzleti elvárások az informatikai rendszerekkel szemben manapság a következők: bevételteremtés, az üzleti folyamatok javítása és automatizálása, hatékonyságnövelés, kultúraváltás az innováció irányába és az ügyfél-elégedettség javítása (Danyi 2007).

\section{FEJLŐDÉSE, SZOLGÁLTATÁSOK}

A vállalati, számítógéppel támogatott információs rendszerek fejlődése a múlt század közepén kezdődött és napjainkban sem ért még véget. Eleinte az adatfeldolgozás, a munka hatékonyságának növelése volt a cél. Ezt követte a 
vezetői információszükségletet kielégítő rendszerek megjelenése. Végül megjelentek azok az információs rendszerek, amelyek fö célként a versenyképesség javítását jelölték meg. Ez a hármas csoportosítás, eltérő hangsúlyokkal, de követhető a szakirodalomban (Wiseman 1985, Galliers-Somogyi 1987, Hirschheim et al. 1988, Kövesi 2007). Applegate és munkatársai (Applegate et al. 1996) négyes csoportosítást alkalmaznak az információtechnológiai korszakok megkülönböztetésére. A korszakok a valóságban nem különülnek el egymástól élesen, inkább egybemosódnak és együtt élnek. Mindegyik technológia folyamatosan fejlődik, újabb és újabb módszerek, technikák épülnek bele vagy kapcsolódnak hozzá (Tarnóczi 2008).

Az információs rendszerek elnevezése, besorolása tekintetében nehézségekbe ütközhetünk. Ennek oka, hogy sokféle szempont szerint igyekeznek csoportosítani a rendszereket, továbbá az újabb és újabb képességekkel felruházott, a tudomány legújabb eredményeit felhasználó rendszerek számos képességgel rendelkeznek, amelyek alapján több csoportba is be lennének sorolhatók.

Egy lehetséges és átfogó osztályozás a következő lehet (Gorry et al. 1971, Long 1989, Reynolds 1991, Boros 1995, Polzer 1996, Roóz-Kozma 2000, Michelberger 2001, Véry 2002, Berde et al. 2003, Chikán 2008):

- Végrehajtási tevékenységet támogató rendszerek: tranzakció feldolgozó rendszerek, folyamatirányító rendszerek, gyártásautomatizálási rendszerek, irodaautomatizálási rendszerek.

- Vezetői munkát támogató rendszerek: stratégiai információs rendszerek, felsővezetői információs rendszerek, valósidejủ elemző rendszerek, egyéni és csoportos döntéstámogató rendszerek, vezetői információs rendszerek.

- Egyéb, átfedő rendszerek: szakértői rendszerek, üzleti információs rendszerek, integrált információs rendszerek, szervezetek közötti információs rendszerek.

A fenti lista korántsem teljes, léteznek - az ellátott funkciók alapján - egyéb rendszerelnevezések is. A fejlődés nem állt meg: egyrészt a már meglévő rendszereket fejlesztik tovább, másrészt újabb fajta rendszerek jelennek meg, így a vállalkozások egyre nagyobb választékból választhatnak (Molnár 2007).

\section{FEJLESZTÉS VAGY VÁSÁRLÁS}

Az informatikai beruházás megvalósulhat saját rendszer fejlesztésével, vagy kulcsrakész rendszer megvásárlásával (majd annak igény szerinti testre szabásával) (Molnár 2002). Újdonságnak számít az informatikai szolgáltatások megrendelése külső szállítótól, vagyis az informatika kiszervezése (Danyi 2007), a különböző tudású felhőalapú szolgáltatások közmü-szerü igénybe vétele.

Az egyedi fejlesztésü információs rendszer előnye, hogy teljesen testre szabott sőt, ha belső fejlesztés történik, akkor a szervezeti titkok egyáltalán nem kerülnek ki a vállalkozásból (Kiss 2007), hátránya viszont, hogy bevezetése lassú és drága (Michelberger 2002). 
A standard, kulcsrakész rendszerek elönye, hogy a fejlesztő külső szakemberek mögött már van tapasztalat, így a bevezetés - viszonylag - gyors (Krotos 2002) és - viszonylag - olcsó, továbbá a rendszer beépített iparági tapasztalatokat tartalmazhat. Ugyanakkor számos példát találhatunk arra a gyakorlatban, hogy egy standard szoftver bevezetése is sok gondot okozhat a vállalkozás számára: ezeket is sokszor költségesnek tartják, a nem megfelelö elökészítés esetén bevezetésük sok időbe kerül és későbbi módosításuk is nehézkes lehet (Upton-Staats 2008). Ez a standard rendszerekkel kapcsolatos kedvezötlen vélemény azonban nem változtat azon, hogy átgondolt tervezés esetén a bevezetésük és használatuk előnyösebb az egyedi fejlesztésủ szoftverrendszerekkel szemben, hiszen az költségei jobban tervezhetőek és nagyobb tapasztalat áll ezen iparági tapasztalatokat is tartalmazó rendszerek mögött.

$\mathrm{Az}$ az általában legelső a vezetői elvárás, amely szerint az informatika lehetőleg müködjön észrevétlenül és egyre olcsóbban (Danyi 2007), sok esetben az informatika kiszervezése révén oldható meg leghatékonyabban. A felhőalapú informatikai szolgáltatásokat a vállalkozások közmü-szerủen vehetik igénybe és e szolgáltatások köre a jövőben bővülni fog.

\section{MEGTÉRÜLÉS}

$\mathrm{Az}$ információs rendszer kiépítése, majd mủködtetése jelentős kezdeti, majd folyamatos anyagi ráfordítást igényel, ezért - jó esetben - fontos kérdés a vállalkozás számára a rendszerük megtérülése.

Bár általában van igény az informatikai rendszer megvalósítására, fejlesztésére, ugyanakkor sokszor fogalmazódik meg a vezetőkben a „kivárás” az informatikai beruházásokkal, fejlesztésekkel kapcsolatban. Leggyakoribb kifogásként a pénzhiány, az ár és a megtérülés problémája mellett a technológiai váltások gyors üteme, a nehézkes integráció, az alkalmazottak ellenállása, az informatikai ismeretek hiánya, az adatbiztonság, a vezetök ellenállása és a jogi szabályozás hiányosságai szerepelnek (Cégvezetés 2007a).

$\mathrm{Az}$ információs többletértékkel bíró rendszerek képesek ugyan az adott vállalkozást, ill. annak vezetöit gazdasági elönyhöz juttatni, de csak az a befektetés térülhet meg, amelyet képesek helyesen is használni, egyébként nincs értelme a rendszer alkalmazásának (Kovács 2003).

Az információs rendszerek felgyorsítják az információáramlást, ami az üzleti siker záloga lehet, ez az előnyük, tehát az információáramlás gyorsaságának pozitív hatása azonban nehezen mérhető, számszerüsíthető.

Egy informatikai beruházásnál jellemzően csak a költségek határozhatók meg konkrét, mérhető formában, míg az elönyök csak, mint könnyen vitatható közvetett hasznok jeleníthetők meg. Éppen ezért nem mindig célszerü az informatikai rendszereket megtérüléshez kötni; inkább az informatikai beruházás elmaradásának következményeit célszerü vizsgálni (Hetyei 2009): „Ha nem használunk korszerü informatikai eszközöket, lemaradunk, veszítünk versenyképességünkböl.”

Végezetül meg kell említeni olyan kutatásokat is (Pitlik 1996, Strassmann 1997), amelyek azt mutatják, hogy a gazdálkodó szervezetek eredményessége és az 
informatikai jellegủ beruházások között pozitív korreláció nem igazolható vissza, sőt néha az ellenkezője látszik bebizonyosodni (ez az ún. információtechnológia termelékenységi paradoxon). Ennek azonban a fö oka, hogy az információtechnológiára költött befektetésekkel helytelen módon akarják segíteni a vállalkozás gazdálkodását, müködését.

\section{VERSENYKÉPESSÉG}

A vállalati információs rendszerekkel kapcsolatban rendre megjelenik a vállalkozások versenyképességhez való hozzájárulás, mint érték.

A versenyképességgel általában foglalkozó írások az információs rendszerek mint eszközök - szerepét a versenyképességben egyáltalán nem, vagy csak áttételesen említik.

- Csath szerint a vállalkozások versenyképessége általánosságban annak az eredménye, hogy a cégek kifejlesztenek és fenntartanak másoktól eltérő versenyelönyöket. Egy másik általános meghatározás alapján a versenyképesség egy vállalkozásnak az a képessége, melynek alapján több értéket tud teremteni versenytársainál (Csath 2010).

- Kimerítő Chikán és munkatársainak fogalmi meghatározása a versenyképességröl, mely szerint: „A vállalati versenyképesség a vállalatnak azon képessége, hogy a társadalmi felelősség normáinak betartása mellett tartósan tud olyan termékeket és szolgáltatásokat kínálni a fogyasztóknak, amelyeket azok a versenytársak termékeinél (szolgáltatásainál) inkább hajlandók a vállalat számára nyereséget biztosító feltételek mellett megfizetni. Ezen versenyképesség feltétele, hogy a vállalat legyen képes a környezeti és vállalaton belüli változások érzékelésére és az ezekhez való alkalmazkodásra a versenytársaknál tartósan kedvezőbb piaci versenykritériumok teljesítésével" (Chikán et al. 2006).

- Hoványi szerint négy fő terület határozza meg egy vállalkozás versenyképességét: a termékek és szolgáltatások minősége, a vállalkozás folyamatainak komplexitása, az ár és a vállalkozás rugalmassága (Hoványi 2006).

- Somogyi azokat a vállalkozásokat tartja versenyképesnek, amelyek versenyképes terméket állítanak elő, tartósan nyereségesek, új piaci pozíciókat szereznek, illetve növelik meglévő pozícióikat, továbbá észlelik a belső és külső környezeti változásokat, és képesek az előzetes, illetve az utólagos reagálásra. A versenyképes vállalkozásnak elegendő és megfelelő minőségü és nehezen másolható erőforrással kell rendelkeznie ahhoz, hogy versenyképes maradjon (Somogyi 2009).

Az előbb felsorolt versenyképességi tényezők mind feltételezik a megfelelő mennyiségü és minőségủ információ beszerzését, majd hatékony feldolgozását az informatikai megoldásokkal, ami pedig biztosíthatja a döntéstámogató, ill. vezetői információs rendszerek támogatásával meghozott döntéseken keresztül a vállalkozás sikerességét. 
Az információs rendszerrel és információval foglalkozó szakirodalmat vizsgálva megtalálhatjuk e fogalmak vállalati versenyképességben betöltött nélkülözhetetlen szerepét:

- Az adattárházakban tárolt több adat és információ jobb döntéseket eredményez (Jurasics 2007).

- A döntések információkkal és informatikai rendszerekkel való támogatottsága a vállalkozás versenyképességére is hatást gyakorol a környezet változásaira való gyorsabb reagálás biztosításán keresztül (Zoltayné et al. 2007).

- $\mathrm{Az}$ is rendszeresen hangzik el érvként, hogy versenyelönybe kerül az a gazdálkodó szervezet, amelyik kiépíti a vállalati adat- és telekommunikációnak rendszerét (Cégvezetés 2007b).

- Az informatika egyszerüsíti, ésszerűsíti a vállalati tevékenységet az információ hatékony kezelésén keresztül; fö elönyei, amiken keresztül biztosítja a versenyelönyt: a termelési költségek csökkentése, a potenciális piaci szegmensek megtalálása, a vállalaton belüli, valamint a környezettel való kommunikáció javítása (Molnár 2007).

Elmondhatjuk tehát, hogy a jelenlegi, gyorsan változó üzleti környezetben a termelés, szolgáltatás hatékonyságát növelö, a vezetőnek információt biztosító, döntéshozatalt támogató információs rendszer a versenyképességet vitathatatlanul meghatározó tényezővé fejlődött. Az azonban, hogy biztosít-e egy adott vállalkozás számára versenyelőnyt, jelentős mértékben múlik a megfelelő használaton.

\section{IRODALOMJEGYZÉK}

Akkerman, R. - Donk, D. P. (2008): Development and application of a decision support tool for reduction of product losses in the food-processing industry. Journal of Cleaner Production. 16(3), pp. 335-342.

Applegate, L. M. - McFarlan, F. W. - McKenney, J. L. (1996): Corporate Information Systems Management: The Issues Facing Senior Executives. Irwin. Chicago.

Arató I. - Schwarczenberger I.-né (1993): Információs rendszerek szervezési módszertana. Computerbooks. Budapest.

Barna Gy.-né (szerk.) (2006): A digitális gyár megvalósítása kis- és középvállalatoknál. Műszakigazdasági információ. Vállalatirányítás. 3(5), pp. 49-65.

Berde Cs. - Dajnoki K. - Dienesné K. E. - Gályász J. - Juhász Cs. - Szabados Gy. (2003): Vezetéselméleti ismeretek. Campus Kiadó. Debrecen.

Bodnár P. (2008): Vállalati informatika. Perfekt Kiadó. Budapest.

Boros J. (1995): Információs rendszerek: az információs rendszerek alapelemei és életciklusa. Magyar-Amerikai Vállalkozási Alap Nemzetközi Menedzser Központ. Budapest.

Cégvezetés (2007a): A kis- és közepes vállalkozások kegyeit keresik az informatikai cégek. Cégvezetés 14(3). http://cegvezetes.hu/2007/03/a-kis-es-kozepes-vallalkozasok-kegyeit-keresikaz-informatikai-cegek/ (letöltve: 2013.10.12.)

Cégvezetés (2007b): Vállalati adat- és telekommunikáció. Cégvezetés. 14(4). http://cegvezetes.hu/2007/04/vallalati-adat-es-telekommunikacio/ (letöltve: 2013.10.12.)

Chikán A. (2008): Vállalatgazdaságtan. Aula Kiadó. Budapest.

Chikán A. - Czakó E. - Kazainé Ónodi A. (2006): Gazdasági versenyképességünk vállalati nézőpontból - Versenyben a világgal 2004-2006 kutatási program. Zárótanulmány. Budapesti Corvinus Egyetem Versenyképesség Kutató Központ. Budapest. 
Csath M. (2010): Versenyképesség-menedzsement. Nemzeti Tankönyvkiadó. Budapest.

Danyi P. (2007): Mit ér az informatika az üzletnek. Harvard Business Manager. 9(5), pp. 17-31.

Élelmiszer (2006): Pénztártól a készletnyilvántartásig. "Általában szeretnék fejleszteni az informatikát". Élelmiszer. 14(3), p. 70.

Élelmiszer (2007): Élelmiszeriparra szabott szoftverek. Programozott munkafolyamatok. Élelmiszer. 15(9), p. 75.

Gábor A. (1993): Számítógépes információrendszerek. Aula Kiadó. Budapest.

Galliers, R. D. - Somogyi E. K. (1987): Applied Information Technology: From Data Processing to Strategic Information Systems. Journal of Information Technology. 2(1), pp. 30-41.

Gorry, G. A. - Scott-Morton, M. A. (1971): A Framework for Management Information Systems. Sloan Management Review. 13(1), pp. 55-70.

Han, J. - Kamber, M. (2004): Adatbányászat. Koncepciók és technikák. Panem Kiadó. Budapest.

Hetyei J. (szerk.) (2009): ERP rendszerek Magyarországon a 21. században. Computerbooks. Budapest.

Hirschheim, R. - Earl, M. J. - Feeny, D. - Locket, M. (1988): An Exploration into the Management of the Information System Function: Key Issues and an Evolutionary Model. Proceedings of the Joint International Symposium on IS: Information Technology Managemet for Productivity and Strategic Advantage. 1988. március. Szingapúr. pp. 4.15-4.38.

Hoványi G. (2006): Vállalatirányítás és menedzselés. http://www.hova nyig.hu/valirany.doc (letöltve: 2010.07.12.)

Jurasics J.-né (szerk.) (2007): Adattárház: hatékonyságnövelő tényező vagy igazi stratégiai versenyelőny forrása? Müszaki-gazdasági információ. Vállalatirányítás. 4(1), pp. 38-51.

Kiss I. (2007): Az üzleti informatika elmélete a gyakorlatban. Információs Társadalomért Alapítvány. Budapest.

Kovács K. (2003): Informatika a vállalatvezetés szolgálatában: új lehetőségek és ezek valóra váltásának feltételei. Kézirat. Szent István Egyetem Gazdaság- és Társadalomtudományi kar Gazdaságelemzési és Módszertani Intézet Gazdasági Informatikai Tanszék. Gödöllő.

Kövesi J. (szerk.) (2007): Menedzsment és vállalkozásgazdaságtan. Budapesti Müszaki és Gazdaságtudományi Egyetem - Typotex Kiadó. Budapest.

Krotos L. (2002): Intelligens megoldások: a döntéstámogató rendszerek világa. Kód Gazdaság- és Médiakutató Intézet. Budapest.

Long, L. (1989): Management Information System. Prentice Hall. New Jersey.

Lucey, T. (1989): Management Information Systems. DP Publications. London.

Mangina, E. - Vlachos, I. P. (2005): The changing role of information technology in food and beverage logistics management: beverage network optimization using intelligent agent technology. Journal of Food Engineering. 70(3), pp. 403-420.

McMeekin, T. A. - Baranyi, J. - Bowman, J. - Dalgaard, P. - Kirk, M. - Ross, T. - Schmid, S. - Zweitering, M. H. (2006): Information systems in food safety management. Journal of Food Microbiology. 112(3), pp. 181-194.

Michelberger P. (2001): Vállalati Információs Rendszerek Jövője. Tanulmány. Gábor Dénes Föiskola. Budapest.

Michelberger P. (2002): Válasszunk ERP rendszert! - A kiválasztás támogatási lehetőségei. Vezetéstudomány. 33(3), pp. 24-28.

Molnár B. (2002): Bevezetés a rendszerelemzésbe. A rendszerszervezés alapjai. Műszaki Könyvkiadó. Budapest.

Molnár L. G. (szerk.) (2007): Az üzleti információs rendszerek fejlödése. Müszaki-gazdasági információ. Vállalatirányítás. 4(1), pp. 31-38.

Murdick, R. G. (1980): MIS Concepts and Design. Prentice Hall. London.

Pitlik L. (1996): Agrárinformatikai szöveggyüjtemény II. Agroconsult. Gödöllő.

Polzer, H. G. (1996): Vezetési elvek és szervezeti formák változásának hatása az információs technológiára. I. k. Miskolc.

Reynolds, G. W. (1991): Information System for Managers. West Publishing Company. St. Paul.

Roóz J. - Kozma I. (2000): Szervezet és vezetés. Magyar Könyvvizsgáló Kamara. Budapest. 
Smyth, W. F. (1977): Vállalati információs rendszer: programszervezési esettanulmány Statisztikai Kiadó Vállalat. Budapest.

Somogyi M. (2009): Versenyképesség a szakirodalomban. A fogalmi megközelítések összegzése és elemzése. Vezetéstudomány. 40(5), pp. 41-52.

Strassmann, P. A. (1997): Will Big Spending on Computers Guarantee Profitability? Datamation. www.strassmann.com/pubs/datamation0297 (letöltve: 2010.07.10.)

Tarnóczi T. (2008): Döntéstámogató rendszerek. Debreceni Egyetem Közgazdaságtudományi Kar. Debrecen.

Upton, D. M. - Staats, B. R. (2008): Radikálisan egyszerü IT. Harvard Business Review. 10(7-8), pp. $51-57$.

Véry Z. (2002): Vezetői információs-rendszerek az agrárgazdaságban. "Integrált irányítási- és információs rendszerek fejlesztése az élelmiszergazdaságban" OTKA T034627. Kézirat. Budapest.

Wallace, T. F. - Kremzar, M. H. (2006): ERP - vállalatirányítási rendszerek. HVG Kiadó. Budapest.

Ward, J. (1998): Az információrendszerek szervezési elvei. Co-Nex Könyvkiadó. Budapest.

Wiseman, Ch. M. (1985): Strategy and Computers. Dow Jones-Irwin, New York.

Zoltayné P. Z. - Wimmer Á. - Szántó R. (2007): Vezetői döntéshozatal és versenyképesség. Vezetéstudomány. 38(5), pp. 18-28. 